\title{
Cardioprotective Role of Saxagliptin through Antioxidant Mechanism in Experimental Myocardial Infarction in STZ Induced Diabetic Rats
}

\section{Mandlem VKK $^{1^{*}}$ and Annapurna $\mathrm{A}^{2}$}

${ }^{1}$ Department of Pharmacology, CMR College of Pharmacy, Hyderabad, Telangana, India

${ }^{2}$ Professor, Department of Pharmacology, A.U College of Pharmaceutical Sciences, Andhra University, Visakhapatnam, Andhra Pradesh, India

*Corresponding author: Mandlem VKK, Associate Professor, Department of Pharmacology, CMR College of Pharmacy, Hyderabad, Telangana, India, Tel: +91 9247896044; E-mail: arunakiran4u@gmail.com

Received date: February 10, 2017; Accepted date: March 03, 2017; Published date: March 10, 2017

Copyright: (c) 2017 Mandlem VKK, et al. This is an open-access article distributed under the terms of the Creative Commons Attribution License, which permits unrestricted use, distribution, and reproduction in any medium, provided the original author and source are credited.

\begin{abstract}
Saxagliptin (Dpp-4 inhibitor) is a newer anti-diabetic drug for type 2 diabetes mellitus. It has beneficial effect on glycemic control and weight neutral but its effects on the heart during ischemic reperfusion periods are not known. We investigated the effect of Saxagliptin on infarct size in a clinically relevant cardiac I/R injury model in type 2 diabetic rats and its underlying cardioprotective effects. Normal and diabetic rats were randomized to receive Saxagliptin $5 \mathrm{mg} / \mathrm{kg}$ b.wt. orally for a period of 4 weeks and were subjected to $30 \mathrm{~min}$ left anterior descending artery coronary artery occlusion followed by $4 \mathrm{~h}$ of reperfusion. Percentage left ventricle infarction, cardiac biomarkers (SGOT, CK, CKMB) oxidative stress markers (malondialdehyde, catalase, SOD) were analysed. When compared to control group, saxagliptin produced significant dose-dependent reduction in percentage infarct volume. Saxagliptin, at $5 \mathrm{mg} / \mathrm{kg}$ b.wt. dose, there was a significant reduction in SGOT, CK CKMB and MDA levels and in contrast there was a significant increase in anti-oxidant enzymes such as SOD and catalase levels. Saxagliptin decreases infarct size and showed significant cardioprotective action mediated by antioxidant mechanisms.
\end{abstract}

Keywords: Saxagliptin; Diabetes; Cardiac ischemia; Reperfusion injury; Antioxidant

\section{Abbreviations:}

CABG: Coronary Artery Bypass Grafting; CAT: Catalase; CK: Creatine Kinase; Dpp-4- Dipeptidyl Peptidase-4; GIP: Gastric Inhibitory Polypeptide; GLP-1: Glucagon Like Peptide-1; I/R: Ischemia-Reperfusion; IHD: Ischemic Heart Disease; LDH: Lactate Dehydrogenase; MDA: Malondialdehyde; ROS: Reactive Oxygen Species; SGOT: Serum Glutamic-Oxaloacetic Transaminase; SOD: Superoxide Dismutase; STZ: Streptozocin; T2DM: Type-2 Diabetes Mellitus; WHO: World Health Organization

\section{Introduction}

Ischemic Heart Disease (IHD) is the single leading cause of death worldwide, accounting for $13.2 \%$ of all deaths globally in 2012 [1]. Ischemia is the clinical condition of an impaired circulation, which results in decreased supply of oxygen and nutrients in the affected tissue. Ischemia can occur through thrombosis or embolism [2]. Restoration of blood flow, termed as reperfusion, is the only effective treatment to prevent irreversible damage and necrosis of the ischemic tissue. Ischemia Reperfusion $(\mathrm{I} / \mathrm{R})$ injury has been referred as a double edged sword [3].

Patients with Type 2 Diabetes Mellitus (T2DM) exhibit an increased risk of cardiovascular mortality compared to non-diabetic subjects $[4,5]$. The percentage of diabetic patients among patients with ischemic heart disease that undergo Coronary Artery Bypass Grafting (CABG) is $7-20 \%$ [6]. Chronic hyperglycemia plays an important role in the development of endothelial dysfunction, oxidative stress and increases generation of advanced glycation end products which results in microvascular dysfunction [7]. In addition to that, hyperglycemia accelerates atherosclerosis which may lead to myocardial infarction [8]. Regulation of glycemic control has the added advantage of reducing the cardiovascular events in T2DM [9].

Glucose homeostasis can be achieved by complex interaction of a spectrum of hormones such as, insulin, glucagon, and amylin including incretins. Incretin dysfunction is regarded as one of the factors contributing to the pathogenesis of T2DM [10]. Therapies that restore incretin activity may reduce the pathophysiologic consequences of diabetes [11].

Dipeptidyl Peptidase-4 (DPP-4) inhibitors are the newer class of compounds that was approved in 2006 for the treatment of T2DM. Their primary mechanism of action is through inhibition of degradation of incretins, such as glucagon like peptide-1 (GLP-1) and Gastric Inhibitory Polypeptide (GIP) [12]. Therapeutic strategies to reduce reperfusion injury and other cardiovascular events in diabetic patients with IHD have been the focus of increasing interest in recent years.

A large number of experimental and clinical trials strongly indicate the potential role for DPP-4 inhibitors limiting myocardial ischemiareperfusion induced injury [13]. Experimental and preclinical studies demonstrated that gliptins played a potential role as cardioprotective drugs [14]. In addition, wide applicability (anti-oxidant, antiinflammatory, free radical scavenging) of DPP-4 inhibitors in cardiovascular research prompted us to select the Saxagliptin for the evaluation of cardioprotective activities in experimental myocardial infarction.

Saxagliptin has the advantage of weight neutral and no risk of hypoglycemia T2DM. In spite of tremendous potentiality of Saxagliptin to protect the heart during ischemia-reperfusion, only few 
studies have reported the cardioprotective actions of Saxagliptin in ischemia reperfusion injury [15]. However, cardioprotective actions of Saxagliptin have not been so far explored in ischemia-reperfusion of diabetic hearts.

\section{Materials and Methods}

\section{Chemicals}

Streptozocin (Sigma Aldrich, India), Nicotinamide (Sigma Aldrich, India), 2,3,5-triphenyl tetrazolium chloride (TTC), thiopentone sodium (Neon laboratories, India) Saxagliptin, Novartis, Hyderabad. Glucose, LDH, SGOT, CK and CK-MB colorimetric kits (Coral Clinisystems, India), superoxide dismutase (SOD), Catalase (CAT) and MDA kits (BIOSPES, China) and all other chemicals used were of analytical grade and purchased locally.

\section{Animals}

Adult Wistar rats weighing 250-270 g were purchased from NIN Hyderabad, Telangana, India. Animals were maintained under a 12/12 $\mathrm{h}$ light/dark cycle in ambient room temperature i.e., $24 \pm 1^{\circ} \mathrm{C}$. Animals were taken care in compliance with the CPCSEA, New Delhi. Experimental protocols were conducted in accordance with the approval of the IAEC.

\section{Induction of diabetes}

Rats were rendered T2DM by single injection of STZ (30 mg/kg i.v) and Nicotinamide ( $150 \mathrm{mg} / \mathrm{kg}$ i.p). After $72 \mathrm{~h}$ animals were confirmed diabetes and those blood glucose levels in the range of $200-250 \mathrm{mg} / \mathrm{dl}$ were used in the present study [16].

\section{Induction of myocardial infarction}

Rats were anaesthetized with thiopental sodium $(30 \mathrm{mg} / \mathrm{kg}$, i.p). A left thoracotomy and pericardiotomy were performed and then marginal branch of the left anterior descending coronary artery (LAD) was identified and occluded for $30 \mathrm{~min}$ followed by reperfusion for $4 \mathrm{~h}$. Rectal temperature was maintained at $37 \pm 0.5^{\circ} \mathrm{C}$. Animals those do not lose righting reflex or which are convulsed during ischemia were excluded from the study [17].

\section{Measurement of percentage left ventricle necrosis}

Rats were divided into groups: Normal, sham control, I/R (ischemia +reperfusion), Saxagliptin treated. Saxagliptin was suspended in $0.1 \%$
$\mathrm{NaCMC}$ and were administered orally at the dose of $5 \mathrm{mg} / \mathrm{kg}$ for a period of four weeks. After the treatment period rats were subjected to ischemia/reperfusion, the heart was removed quickly and washed with ice cold buffer and left ventricle was separated and later sliced into coronal sections of $2 \mathrm{~mm}$ thickness [18] The slices were immersed in $1 \%$ solution of TTC stain; red formazan pigment was observed in viable cells, whereas dead cells appeared pale in colour and was unstained [19]. Necrotic infarcted tissue was separated and weighed. Percent left ventricle necrosis was calculated [16].

\section{Estimation of oxidative stress markers and biochemical markers}

At the end of reperfusion blood was collected through cardiac puncture and serum was separated for estimating the enzyme markers LDH (IFCC), SGOT (IFCC), CK (IFCC), CKMB (IFCC). Left ventricle tissue was separated immediately after reperfusion period and washed with ice cold buffer and subjected to homogenization with ice cold trisbuffer and the supernatant was used for the estimation of oxidative markers like MDA [20], SOD [21], CAT [22]. All the above parameters were analysed according to the procedures in the product manual supplied with the commercial kits.

\section{Statistical analysis}

All the values were expressed as mean \pm S.D. and analysed by oneway ANOVA followed by Tukey's $t$ test $(p \leq 0.05)$. The significance of differences was estimated by two-way analysis of variance. The statistical analysis was processed using Graph Pad Prism Version 5.0.

\section{Results}

\section{Percentage left ventricle necrosis}

Percentage left ventricle necrosis in normal rats following cardiac $\mathrm{I} / \mathrm{R}$ injury was found to be $49.05 \pm 1.76$. Significant reduction in infarction was observed at the dose level of $5 \mathrm{mg} / \mathrm{kg}$ and $10 \mathrm{mg} / \mathrm{kg}$ of Saxagliptin (Table 1). Similarly, percentage left ventricle necrosis in diabetic rats following cardiac I/R injury was found to be $59.06 \pm 1.86$. Significant reduction in infarction was observed at the dose levels of 5 $\mathrm{mg} / \mathrm{kg}$ and $10 \mathrm{mg} / \mathrm{kg}$ administration of Saxagliptin (Table 1) in acute study. The effect of Saxagliptin in diabetic groups was more pronounced when compared to normal groups. Hence, for the chronic study the dose of Saxagliptin $5 \mathrm{mg} / \mathrm{kg}$ was selected.

\begin{tabular}{|l|l|l|l|l|l|l|l|l|}
\hline Group & $\begin{array}{l}\text { Normal } \\
\text { Sham } \\
\text { control }\end{array}$ & $\begin{array}{l}\text { Normal } \\
\text { control } \\
(\mathbf{I} / \mathbf{R})\end{array}$ & $\begin{array}{l}\text { Normal } \\
\text { Saxagliptin } \\
\mathbf{5} \mathbf{~ m g}\end{array}$ & $\begin{array}{l}\text { Normal } \\
\text { Saxagliptin } \\
\mathbf{1 0} \mathbf{~ m g}\end{array}$ & $\begin{array}{l}\text { Diabetic } \\
\text { Sham control }\end{array}$ & $\begin{array}{l}\text { Diabetic } \\
\text { Control } \\
\text { (I/R) }\end{array}$ & $\begin{array}{l}\text { Diabetic } \\
\text { Saxagliptin } \\
\mathbf{5} \mathbf{~ m g}\end{array}$ & $\begin{array}{l}\text { Diabetic } \\
\text { Saxagliptin } \\
\mathbf{1 0} \mathbf{~ m g}\end{array}$ \\
\hline $\begin{array}{l}\text { Infarct size } \\
\text { Mean } \pm \text { SD }\end{array}$ & $5.09 \pm 0.48$ & $\begin{array}{l}49.05 \\
\pm 1.76\end{array}$ & $\begin{array}{l}21.02 \\
\pm 1.29\end{array}$ & $\begin{array}{l}9.33 \\
\pm 0.56\end{array}$ & $\begin{array}{l}9.67 \\
\pm 0.56\end{array}$ & $\begin{array}{l}59.06 \\
\pm 1.86\end{array}$ & $\begin{array}{l}23.98 \\
\pm 2.55\end{array}$ & $\begin{array}{l}8.97 \\
\pm 1.35\end{array}$ \\
\hline $\begin{array}{l}\text { Percentage } \\
\text { protection }\end{array}$ & - & - & $57.14^{*}$ & $80.97^{*}$ & - & - & $59.39^{*}$ & $84.81^{*}$ \\
\hline
\end{tabular}

Table 1: Effect of acute administration of saxagliptin on infarct size (\% left ventricle necrosis) in normal and diabetic rats. All values were expressed as mean \pm S.D $(n=6),{ }^{*} p<0.05$. 
Citation: Mandlem VKK, Annapurna A (2017) Cardioprotective Role of Saxagliptin through Antioxidant Mechanism in Experimental Myocardial Infarction in STZ Induced Diabetic Rats. Clin Exp Pharmacol 7: 233. doi:10.4172/2161-1459.1000233

Page 3 of 5

\section{Effect on biochemical markers}

Significant elevation of LDH (5086.33 \pm 120.31$)$, SGOT (1522.5 \pm $36.91)$, CK $(3352 \pm 251.89$ and CK-MB $(546 \pm 13.62)$ indicates loss of viability and structural damage to cardiac tissue, as evidenced by diabetic groups subjected to I/R injury. Treatment with saxagliptin 5 $\mathrm{mg} / \mathrm{kg}$ significantly reduced the elevated levels of $\mathrm{LDH}(695.66 \pm$ 40.54), SGOT (336 \pm 27.14$)$ CK (393.88 \pm 32.18$)$ and CK-MB (127.83 \pm 9.82) in diabetic groups when compared to Diabetic groups subjected to I/R injury (Table 2 and Figure 1).

\begin{tabular}{|l|l|l|l|}
\hline Marker & $\begin{array}{l}\text { Diabetic Sham } \\
\text { Control }\end{array}$ & Diabetic I/R Control & $\begin{array}{l}\text { Saxagliptin } \\
\text { treatment } \\
\text { mg/kg }\end{array} \quad \mathbf{0 . 0}$ \\
\hline LDH (U/L) & $347.5 \pm 11.57$ & $5086.33 \pm 120.31$ & $695.66 \pm 40.54$ \\
\hline SGOT (U/L) & $162.83 \pm 7.22$ & $1522.5 \pm 36.91$ & $336 \pm 27.14$ \\
\hline CK (U/L) & $158.83 \pm 11.14$ & $3352 \pm 251.89$ & $393.88 \pm 32.18$ \\
\hline CK-MB (U/L) & $25 \pm 2.36$ & $546 \pm 13.62$ & $127.83 \pm 9.82$ \\
\hline & - & $a$ & $a, b$ \\
\hline
\end{tabular}

Table 2: Effect of Saxagliptin on cardiac enzyme biomarkers in ischemia-reperfusion induced myocardial infarction in STZ induced diabetic rats. Statistical significance was presented in the last row of the table. All values were expressed as mean $\pm S D(n=6),{ }^{a} p<0.05$ vs. diabetic sham control; ${ }^{b} \mathrm{p}<0.05$, vs. diabetic control I/R.

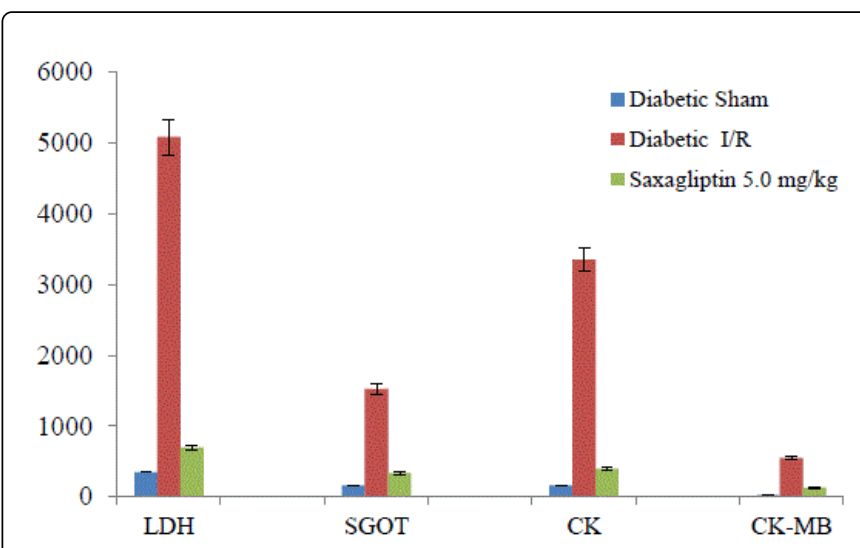

Figure 1: Effect of Saxagliptin on cardiac enzyme biomarkers in ischemia-reperfusion induced myocardial infarction in STZ induced diabetic rats.

\section{Effect on oxidative stress markers}

To determine the effect of Saxagliptin following cardiac I/R injury on oxidative stress parameters, malondialdehyde, superoxide dismutase and catalase levels.

Effect on cardiac malondialdehyde levels: Malondialdehyde levels in the cardiac tissue were significantly higher in diabetic I/R (183.30 \pm 2.84) group compared to sham operated rats $(5.51 \pm 1.08)$. In rats treated Saxagliptin $5 \mathrm{mg} / \mathrm{kg}$, the elevated levels of MDA due to I/R injury were significantly attenuated in diabetic groups $(40.88 \pm 1.39)$ respectively (Table 3 and Figure 2).

\begin{tabular}{|l|l|l|l|}
\hline Marker & $\begin{array}{l}\text { Diabetic Sham } \\
\text { Control }\end{array}$ & $\begin{array}{l}\text { Diabetic } \\
\text { control }\end{array}$ & $\begin{array}{l}\text { Saxagliptin } \\
\text { treatment } \\
\mathbf{m g} / \mathbf{k g}\end{array} \quad \mathbf{5 . 0}$ \\
\hline $\begin{array}{l}\text { MDA } \\
\text { (nmol/g tissue) }\end{array}$ & $5.51 \pm 1.08$ & $183.30 \pm 2.84$ & $40.88 \pm 1.39$ \\
\hline $\begin{array}{l}\text { SOD } \\
(\mathrm{U} / g \text { tissue) }\end{array}$ & $29.69 \pm 1.50$ & $10.22 \pm 1.25$ & $26.28 \pm 1.93$ \\
\hline $\begin{array}{l}\text { CAT } \\
(\mathrm{U} / \mathrm{g} \text { tissue })\end{array}$ & $25.89 \pm 0.99$ & $9.2 \pm 0.40$ & $22.67 \pm 0.67$ \\
\hline & & $\mathrm{a}$ & $\mathrm{a}, \mathrm{b}$ \\
\hline
\end{tabular}

Table 3: Effect of Saxagliptin on cardiac oxidative stress markers in ischemia-reperfusion induced myocardial infarction in diabetic rats. Statistical significance was presented in the last row of the table. All values were expressed as mean \pm S.D $(n=6),{ }^{a} p<0.05$ vs. diabetic sham control; ${ }^{b} \mathrm{p}<0.05$, vs. diabetic control $\mathrm{I} / \mathrm{R}$.

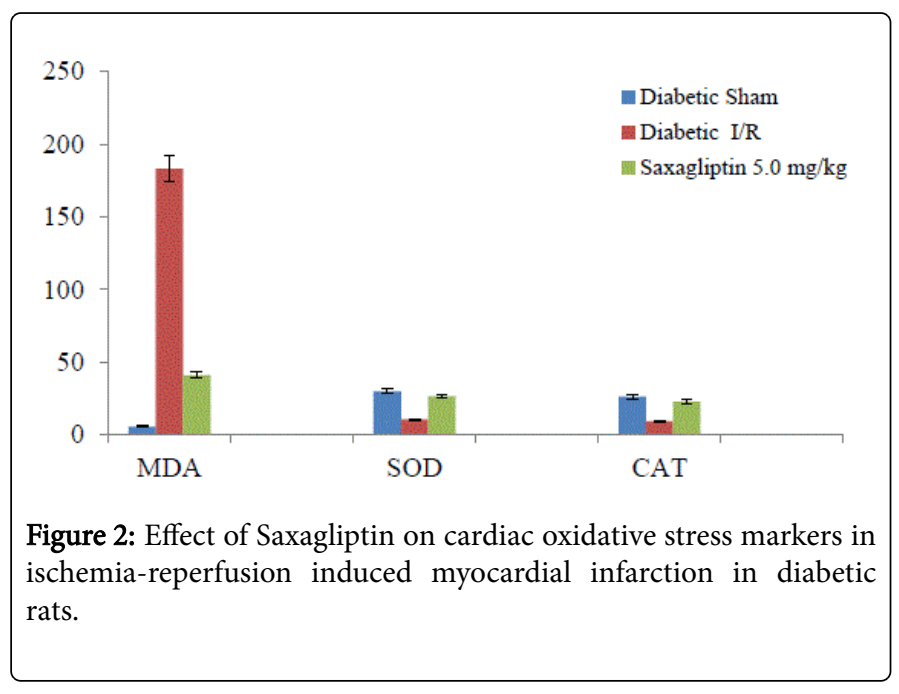

Effect on cardiac SOD levels: SOD levels in the cardiac tissue of diabetic rats subjected to $\mathrm{I} / \mathrm{R}(10.22 \pm 1.25)$ were significantly decreased compared to sham operated rats $(29.69 \pm 1.50)$. In Saxagliptin treated rats, levels of SOD $(26.28 \pm 1.93)$ were significantly increased when compared to diabetic I/R group (Table 3 and Figure 2).

Effect on cardiac CAT levels: CAT levels in the cardiac tissue of diabetic rats subjected to I/R $(9.2 \pm 0.40)$ were significantly decreased compared to sham operated rats $(25.89 \pm 0.99)$. In Saxagliptin treated rats, levels of CAT $(22.67 \pm 0.67)$ were significantly increased when compared to diabetic I/R group (Table 3 and Figure 2).

\section{Discussion}

Reperfusion injury is the result of complex interactions between substances accumulating during ischemia and those produced after reperfusion. Many studies demonstrated several mechanisms and mediators of reperfusion injury of which most frequently cited include oxygen free radicals, intracellular calcium overload, endothelial microvascular dysfunction and altered myocardial metabolism $[23,24]$. Reperfusion is also a potent stimulus for neutrophil activation and accumulation, which in turn serve as potent stimuli for reactive oxygen species production [25]. Invasion and activation of neutrophil, 
granulocytes together with an explosive release of oxygen free radicals are considered to be the two major events contributing to the pathophysiological derangements [26].

Diabetes itself increases the oxidative stress with in the myocardium [27]. Therefore, it was suggested that the greater degree of injury demonstrated in diabetic rats could be due to a result of increased oxidative stress within the diabetic myocardium and increased neutrophil accumulation in the diabetic rats contributing to increased ischemia-reperfusion injury. The results showed significantly larger infarct size in diabetic rats when compared to normal rats subjected to ischemia-reperfusion injury. The infarct size was significantly reduced by saxagliptin in both normal and diabetic rats in the present study This was in conformity with the previous studies reporting the infarct size limiting effect of DPP-4 inhibitors [28-30].

LDH, SGOT, CK and CK-MB are the good enzymatic biochemical markers of myocardial damage. Leakage of these intracellular enzymes occurs during stress conditions like I/R injury. Increased generation of ROS species during I/R injury oxidises membrane lipids and causes structural damage to the cell membrane. LDH and SGOT play an important role in energy metabolism particularly during hypoxia conditions. $\mathrm{CK}$ and $\mathrm{CK}-\mathrm{MB}$ provide energy during contraction process. Leakage of these cytosolic enzymes indicates myocardial damage. Many studies have shown that myocardial $I / R$ injury increased the release of $\mathrm{LDH}[31]$ and $\mathrm{CK}-\mathrm{MB}$ in diabetic rats $[32,33]$.

Treatment with saxagliptin decreased the levels of LDH, SGOT, $\mathrm{CK}$ and CK-MB enzymes significantly. Therefore, the results represent that saxagliptin prevents oxidative damage to cell membrane caused during ischemia reperfusion injury. The mechanism might be attributed to scavenging lipid peroxidation products. This mechanism is partially responsible for its cardioprotective effect against ischemia reperfusion injury in diabetic rats. Our results are in agreement with previous studies; sitagliptin pre-treatment decreased the release of LDH and CK-MB. In another study treatment with trigonelline and sitagliptin for a period of 9 weeks reduced LDH, CK and CK-MB levels in diabetic rats [34].

The antioxidant defence mechanisms that are developed in heart tissue are SOD, CAT etc. play a very important role in scavenging the ROS particularly when subjected to oxidative stress [35]. During diabetes, these antioxidant defence mechanisms are down regulated further exaggerating the oxidative damage during ischemia reperfusion injury [36]. The results of the present study also demonstrated that the exaggerated oxidative stress in diabetic ischemia-reperfusion injury was clearly evidenced by increased levels of MDA and decreased antioxidant enzyme levels of SOD and CAT in heart tissue [37,38]. Saxagliptin treatment offered significant cardioprotection by reduced lipid peroxidation and increased SOD and CAT levels.

\section{Conclusion}

We have summarized the cardioprotective effect of Dpp-4 inhibitor Saxagliptin that have been used as anti-diabetic drug. Our study showed that Saxagliptin offers cardioprotection by limiting the infarct size via antioxidant effect. These studies show that saxagliptin will have a beneficial effect not only on blood glucose level but also on heart in the settings of myocardial I/R injury in diabetic rats. It would be interesting to evaluate the effect of saxagliptin on cardiac contractility in a more severe model of cardiac I/R injury. There is no sufficient data on DPP-4 inhibition in cardiac I/R injury in humans yet. However the cardiovascular outcome in saxagliptin treated patients showed a decreased rate in stroke, cardiovascular death and myocardial infarction compared to other anti-diabetic therapies [15]. Mechanisms shown in the present study might contribute to the beneficial effects. It would be of interest to evaluate the saxagliptin also in I/R injury of the kidney.

\section{References}

1. http://www.who.int/mediacentre/factsheets/fs310/en/

2. Duehrkop C, Rieben R (2014) Ischemia/reperfusion injury: effect of simultaneous inhibition of plasma cascade systems versus specific complement inhibition. Biochem Pharmacol 88: 12-22.

3. Braunwald E, Kloner RA (1985) Myocardial reperfusion: a double-edged sword? J Clin Invest 76: 1713-1719.

4. Haffner SM, Lehto S, Ronnemaa T, Pyorala K, Laakso M (1998) Mortality from coronary heart disease in subjects with type 2 diabetes and in nondiabetic subjects with and without prior myocardial infarction. $\mathrm{N}$ Engl J Med 339: 229-234.

5. Grundy SM, Benjamin IJ, Burke GL, Chait A, Eckel RH, et al. (1999) Diabetes and cardiovascular disease a statement for healthcare professionals from the American Heart Association. Circulation 100: 1134-1146.

6. Hausenloy DJ, Yellon DM (2013) Myocardial ischemia-reperfusion injury: a neglected therapeutic target. J Clin Invest 123: 92-100.

7. Mohammadzadeh F, Desjardins JF, Tsoporis JN, Proteau G, Leong-Poi H et al. (2013) S100B: Role in cardiac remodelling and function following myocardial infarction in diabetes. Life Sciences 92: 639-647.

8. Cai XY, Lu L, Wang YN, Jin C, Zhang RY, et al. (2011) Association of increased S100B, S100A6 and S100P in serum levels with acute coronary syndrome and also with the severity of myocardial infarction in cardiac tissue of rat models with ischemia-reperfusion injury. Atherosclerosis 217: 536-542.

9. Baggio LL, Drucker DJ (2007) Biology of incretins: GLP-1 and GIP. Gastroenterology 132: 2131-2157.

10. Drucker DJ (2006) The biology of incretin hormones. Cell Metabol 3: 153-165.

11. Ahren B, Simonsson E, Larsson H, Landin-Olsson M, Torgeirsson H, et al. (2002) Inhibition of dipeptidyl peptidase IV improves metabolic control over a 4 -week study period in type 2 diabetes. Diabetes Care 25: 869-875.

12. Vickers SP, Cheetham SC, Birmingham GD, Rowley HL, Headland KR, et al. (2012) Effects of the DPP-4 Inhibitor, Linagliptin, in Diet-Induced Obese Rats:A Comparison in Naive and Exenatide-Treated Animals. Clin Lab 58: 787-799.

13. Ban K, Hui S, Drucker DJ, Husain M (2009) Cardiovascular consequences of drugs used for the treatment of diabetes: potential promise of incretin-based therapies. J Am S Hyp 3: 245-259.

14. Hocher B, Reichetzeder C, Alter ML (2012) Renal and cardiac effects of DPP-4 inhibitors-from preclinical development to clinical research. Kidney and Blood Pressure Research 36: 65-84.

15. Frederich R, Alexander JH, Fiedorek FT, Donovan M, Berglind N, et al. (2010) A systematic assessment of cardiovascular outcomes in the saxagliptin drug development program for type 2 diabetes. Postgrad Med 122: 16-27.

16. Challa SR, Akula A, Metla S, Gopal PN (2011) Partial role of nitric oxide in infarct size limiting effect of quercetin and rutin against ischemiareperfusion injury in normal and diabetic rats. Indian J Exp Biol 49: 207-210.

17. Annapurna A, Reddy CS, Akondi RB, Rao SR (2009) Cardioprotective actions of two bioflavonoids, quercetin and rutin, in experimental myocardial infarction in both normal and streptozotocininduced type I diabetic rats. J Pharm Pharmacol 61: 1365-1374. 
Citation: Mandlem VKK, Annapurna A (2017) Cardioprotective Role of Saxagliptin through Antioxidant Mechanism in Experimental Myocardial Infarction in STZ Induced Diabetic Rats. Clin Exp Pharmacol 7: 233. doi:10.4172/2161-1459.1000233

Page 5 of 5

18. Briyal S, Gulati K, Gulati A (2012) Repeated administration of exendin-4 reduces focal cerebral ischemia-induced infarction in rats. Brain Res 1427: 23-34.

19. Bederson JB, Pitts LH, Tsuji M, Nishimura MC, Davis RL, et al. (1996) Rat middle cerebral artery occlusion: evaluation of the model and development of a neurologic examination. Stroke 17: 472- 476.

20. Okhawa H, Ohishi N, Yagi K (1979) Assay of lipid peroxides in animal tissue by thiobarbituric acid reaction. Anal Biochem 95: 351-358.

21. Kakkar P, Das B, Viswanathan PN (1994) A modified spectrophotometric assay of superoxide dismutase. Ind J Bio Chem Biophys 21:130-132.

22. Aebi H (1974) Catalase: methods in enzymatic analysis. Vol. II. In: Bergmer (ed.) pp: 673-694.

23. Carden DL, Granger DN (2000) Pathophysiology of ischaemiareperfusion injury. J Pathol 190: 255-266.

24. Agati L (1999) Microvascular integrity after reperfusion therapy. Am Heart J 138: S76-S78.

25. Jordan JE, Zhao ZQ, Vinten-Johansen J (1999) The role of neutrophils in myocardial ischemia-reperfusion injury. Cardiovasc Res 43: 860-878.

26. Leo GK, Enis N, David FS (2005) Reactive oxygen species as mediators of cardiac injury and protection: The Relevance to Anesthesia Practice. Anesth Analg 101: 1275-1287.

27. Verma S, Fedak PW, Weisel RD, Butany J, Rao V, et al. (2002) Fundamentals of reperfusion injury for the clinical cardiologist. Circulation 105: 2332-2336.

28. Hausenloy DJ, Whittington HJ, Wynne AM, Begum SS, Theodorou L, et al. (2013) Dipeptidyl peptidase-4 inhibitors and GLP-1 reduce myocardial infarct size in a glucose-dependent manner. Cardiovasc Diabetol 12: 154.

29. Hocher B, Sharkovska Y, Mark M, Klein T, Pfab T (2013) The novel DPP-4 inhibitors linagliptin and BI 14361 reduce infarct size after myocardial ischemia/reperfusion in rats. Int J Cardiol 167: 87-93.
30. Huisamen B, Genis A, Marais E, Lochner A (2011) Pre-treatment with a DPP-4 inhibitor is infarct sparing in hearts from obese, pre-diabetic rats. Cardiovasc Drugs Ther 25: 13-20.

31. Song L, Kang C, Sun Y, Huang W, Liu W, et al. (2016) Crocetin Inhibits Lipopolysaccharide-Induced Inflammatory Response in Human Umbilical Vein Endothelial Cells. Cell Physiol Biochem 40: 443-452.

32. Khalil PN, Neuhof C, Huss R, Pollhammer M, Khalil MN, et al. (2005) Calpain inhibition reduces infarct size and improves global hemodynamics and left ventricular contractility in a porcine myocardial ischemia/reperfusion model. Eur J Pharmacol 528: 124-131.

33. Sun D, Huang J, Zhang Z, Gao H, Li J, et al. (2012) Luteolin limits infarct size and improves cardiac function after myocardium ischemia/ reperfusion injury in diabetic rats. PLoS ONE 7: e33491.

34. Kamble HV, Bodhankar SL (2014) Cardioprotective effect of concomitant administration of trigonelline and sitagliptin on cardiac biomarkers, lipid levels, electrocardiographic and heamodynamic modulation on cardiomyopathy in diabetic Wistar rats. Biomed Aging Pathol 4: 335-342.

35. Dhalla NS, Elmoselhi AB, Hata T, Makino N (2000) Status of myocardial antioxidants in ischemia-reperfusion injury. Cardiovasc Res 47: 446-456.

36. Li H, Bian Y, Zhang N, Guo J, Wang C, et al. (2013) Intermedin protects against myocardial ischemia-reperfusion injury in diabetic rats. Cardiovas Diabetol 12: 91.

37. Xia Z, Guo Z, Nagareddy PR, Yuen V, Yeung E, et al. (2006) Antioxidant $\mathrm{N}$-acetylcysteine restores myocardial Mn-SOD activity and attenuates myocardial dysfunction in diabetic rats. Eur J Pharmacol 544: 118-125.

38. Murali R, Karthikeyan A, Saravanan R (2013) Protective effects of dlimonene on lipid peroxidation and antioxidant enzymes in streptozotocin-induced diabetic rats. Basic Clin Pharmacol Toxicol 112: $175-181$. 